\title{
Az állam felelössége a történeti károk kialakulásában, megelőzésében és kezelésében, a területek hasznosítására vonatkozó kitekintéssel
}

\author{
The Responsibility of the State in the Prevention and Management \\ of Environmental Damage with Regard to Spatial Planning
}

\begin{abstract}
ABSZTRAKT
A tanulmány egy sajátos, új perspektívából tekint az állam felelösségére a történeti károkkal kapcsolatban: a szennyezett területek területhasználati módjának meghatározására vonatkozó legújabb szabályozási eredmények tükrében (is) elemzi annak alkotmányos kereteit. Ennek érdekében röviden vázolja az állami felelősségi körbe tartozó kármentesítések történetét, eltérő szabályozási és intézményrendszeri korszakait napjainkig, illetve azt, hogy az épített környezet alakitása és védelme körében bevezetett, rozsdaövezeti akcióterületek új jogintézménye menynyiben reflektál erre a negyedszázados folyamatra.
\end{abstract}

Kulcsszavak: kármentesítés, rozsdaövezet, épített környezet, területhasználat-tervezés, történeti kár

\begin{abstract}
The study aims to examine the constitutional responsibility of the State for environmental damage from a specific new perspective: it analyses its constitutional framework with regard to recent regulatory tools on spatial planning of the contaminated areas. To this end it briefly outlines the history of the remediation of areas falling within the State's responsibility, its different regulatory and institutional models to date and the extent to which the newly introduced legal instrument in the act on formation and protection and of the built environment of brownfield action areas reflects this quarter-century process.
\end{abstract}

Keywords: remediation, brownfield, built environment, spatial planning, environmental damage

* Dr. Agócs llona, munkatárs, Alapvető Jogok Biztosának Hivatala, a Jövő Nemzedékek Érdekeinek Védelmét Ellátó Biztoshelyettes Titkársága, Budapest; megbízott oktató, Szent István Egyetem Tájépítészeti és Településtervezési Kar; e-mail: Agocs.Ilona@ajbh.hu. A tanulmány a szerző saját véleményét tartalmazza. 
a Hortobágy határán, Balmazújváros-Lászlóházán elhelyezett hordókból szivárgó veszélyes anyagok ${ }^{2}$ okozta, szabad szemmel is jól érzékelhető szennyezés.

Ezekben a sajtóérdeklődést is generáló időszakokban a szakemberek által jól ismert, évtizedes diskurzus szinte változatlan érvei és ellenérvei kerülnek újra és újra felszínre. Ez azt a benyomást kelti, hogy a „gazdátlanul” maradt és akár jól ismert, komoly (humán)ökológiai kockázatot hordozó szennyezések felszámolása, a történeti károk kezelése megoldhatatlan, hosszú távon sem kezelhető terhes környezeti öröksége a jelen generációknak. A szennyezett területek elhelyezkedésüktöl függetlenül akár évtizedekre elhagyott és elhagyatott, hasznosít(hat)atlan és funkciótlan, „,halott” vidékként ékelödnek az épített és természeti környezet elegyébe. Mindeközben a felszín alatti és feletti vízkészlet és a földterület is véges javunk, szükösen rendelkezésünkre álló, fogyó természeti erőforrásunk. ${ }^{3}$

A megoldhatatlanságra vonatkozó következtetés részben helytálló is. Nem csupán hazánkban, de a világ számos országában ${ }^{4}$ jelent komoly kihívást a történeti, hátrahagyott környezeti károk kezelése, felszámolása vagy legalább az arra való törekvés, majd pedig, annak eredményétől függően, az adott terület elért állapotához igazodó rendeltetésének meghatározása. Az okok szerteágazóak: akadnak a történetiségből fakadó nehézségek, technikai - ebböl adódóan ismeretbeli - és pénzügyi korlátok is, amelyek valóban rendkívül nehéz és komplex, interdiszciplináris megközelítésmódot igénylő problémává alakítják a környezeti kármentesítés kérdéskörének ezt a specifikus, állami felelősségi körbe tartozó szegmensét (is). Ugyanakkor éppen ez teszi szükségszerűvé annak folyamatos napirenden tartását és az állam rendszerszintű megközelítésmódját, a tervszerủ intézkedési csomagok kialakítását és azok következetes végrehajtását, végrehajtatását.

Mindez a jelen generációknak nem csupán a generációk közti igazságosság és szolidaritás elvén alapuló, morális kötelezettsége - azaz hogy akik megtapasztalják a „mérgezett örökség” terhét, igyekezzenek azt nem továbbadni -, hanem az Alaptörvényben deklarált ${ }^{5}$ alkotmányos kötelezettsége és felelössége is. Jelen munka célja egyfelöl ezen alkotmányos kereteknek az államra vonatkozó vizsgálata, rövid történeti vázlattal az elmúlt évtizedek szabályozási és finanszírozási koncepcióiról;

${ }^{1}$ A szennyezés története és megismerhető alapadatai megtalálhatóak a Greenpeace Magyarország honlapján, a „Mérgezett Örökségünk, Szennyezett területek és időzített vegyi bombák Magyarországon” cím alatt. https://hu.greenpeace.org/mergezett-oroksegunk/bvm/ (2020. 11. 10.).

${ }^{2}$ Lásd a Greenpeace Magyarország honlapján: https://hu.greenpeace.org/mergezett-oroksegunk/hortobagy/ (2020. 11. 10.); valamint a jövő nemzedékek szószólójának 2014. évi beszámolója, 270.: https://www.ajbh. hu/documents/10180/2119301/AJBH+Beszámoló+2014/e4cb6abb-2b16-4f67-bcdf-e24ccb74cca2?version= 1.0\&inheritRedirect=true (2020. 11. 10.).

${ }^{3}$ Bora Gyula-Korompai Attila (szerk.): A természeti erőforrások gazdaságtana és földrajza. Aula, Budapest, 2001, 428.

${ }^{4}$ Az Európai Környezetvédelmi Ügynökség a „szennyezett területek megtisztitásának és kezelésének változásai” indikátor segítségével átfogó képet igyekszik adni az uniós országok szennyezett területeinek kezeléséröl, felméréséről és az ismert területek megtisztitásának üteméröl, illetve ennek változásairól. https://www. eea.europa.eu/data-and-maps/indicators/progress-in-management-of-contaminated-sites-3/assessment (2020. 11. 10.).

${ }^{5}$ Ezzel összefüggően a jövő nemzedékek érdekeinek védelme megjelenik az Alaptörvény Nemzeti Hitvallás részében mint utódainkért vállalt felelősség, valamint $\mathrm{P}$ ) cikkében és a nemzeti vagyonról szóló 38. cikkében is. 
másfelöl pedig ezen alkotmányos kereteknek kifejezetten az építésügyi ágazat legújabb jogalkotási eredményeinek tükrében történő értékelése. A tanulmány tehát az értelmezési spektrum sajátos szempontokkal, a szennyezett területek használhatóságának és hasznosításának meghatározásával összefüggő bővítésére tett kísérlet.

A leírtak gyakorlati szempontból közelítik a témakört, személyes, szakmai, oktatói tevékenység során szerzett tapasztalatok lecsapódásai, kérdései és következtetései. E tanulmány nem elméleti megközelítésü és szintetizáló mü, nem törekszik a kapcsolódó ágazati szakirodalmak teljes körü bemutatására és felvázolására - már csak a terjedelmi korlátok okán sem. Jóval inkább egy új, sajátos perspektívát kíván felvillantani a legújabb szabályozási fejlemények tükrében, felhívva a figyelmet az elméleti kérdések tisztázásának szükségességére is.

\section{Az elmúlt évtizedek tendenciái a történeti kár fogalmának, eredetének és az állam kapcsolódó szerepköreinek meghatározásában}

\subsection{A történeti kár fogalma, kialakulása, „mérgezett örökségünk”}

A „történeti kár” nem a jogi szabályozás szintjén bevett fogalom. A köznyelvben azokra a múltból eredő, hátrahagyott tartós szennyezésekre utal, amelyek jellemzően még a rendszerváltás előtti időszakból, akár az elmúlt évszázadból erednek. Ezeknek a tartós környezeti károknak az okozói az ország egykori politikai, gazdasági berendezkedéséhez igazodóan a Magyar Állam tulajdonában áló nehéz- vagy egyéb ipari termelő üzemek, tanácsok voltak, illetve jelentős mértékben a magyar és a betelepült szovjet hadsereg. ${ }^{6}$ Ebben az időszakban - noha a nemzetközi folyamatokkal ${ }^{7}$ párhuzamosan 1976 óta létezik a környezet védelmére irányuló szabályozás $^{8}$ - a környezet és általában az emberi egészség védelme egészen más súllyal, más megközelítésben, nem utolsósorban korábbi, mára nagyobb részben meghaladott tudományos ismeretekre alapozva volt jelen. A szennyező anyagok jellemzői, terjedésük és az ökológiai összefüggések ${ }^{9}$ nem képezték a döntéshozatali mechanizmusok integrált részét. Ennek köszönhetően számos máig ható, komoly egészségügyi kockázatot jelentő, és kármentesítésre váró terület található hazánkban. ${ }^{10}$

\footnotetext{
${ }^{6}$ A Nemzeti Fejlesztési Minisztérium OKKP Társasági Alprogram keretében a 2014-2020 programozási időszakban megvalósítani tervezett kármentesítési projektek stratégiai tervezése, KEOP-7.9.0/12-0037, vitaanyag, 2015. május.

${ }^{7}$ Elsősorban az 1972-es stockholmi ENSZ konferencia az Emberi Környezetröl. A korszakról lásd bővebben: Környezetvédelmi és Területfejlesztési Minisztérium: Nemzetközi Környezetvédelmi és Természetvédelmi Egyezmények, 1994. http://real.mtak.hu/65978/1/1994Kornyezet_Egyezmenyek.pdf (2020. 11. 10.).

8 1976. évi II. törvény az emberi környezet védelméröl.

${ }^{9}$ Az Európai Parlament 2017. október 26-i, a környezeti kár megelőzése és felszámolása tekintetében a környezeti felelösségröl szóló, 2004. április 21-i 2004/35/EK európai parlamenti és tanácsi irányelv (környezeti felelősségről szóló vagy ELD irányelv) alkalmazásáról szóló állásfoglalásának L pontja megfogalmazásában „az új tudományos felismerések alapján az ipari tevékenységek okozta szennyezés akár ma még nem sejtett hatást is gyakorolhat mind a környezetre, mind az emberekre, és ez veszélyezteti az emberi egészséget, a fenntarthatóságot, valamint a biológiai és bioevolúciós folyamatok egyensúlyát". HL C 346, 2018.9.27., 185.

${ }^{10}$ Megjegyzendő, hogy az Országos Környezeti Kármentesítési Program (OKKP) részét képező ún. Nemzeti Kármentesítési Prioritási Lista, amely a kármentesítésre váró területeket kiterjedés, kockázati és egyéb
} 
Tekintve azonban, hogy a környezet alakulása és alakítása mind folyamatok, a történeti kár fogalma a jelen szempontjából és a múlt tapasztalatai alapján a fentinél tágabb körben is meghatározható. Érthető lehet alatta a földtani közeg és a felszín alatti vizek minden olyan feltáratlan vagy kezeletlen, vagy csupán részben, a humánökológiai kockázat kizárásának szintje alatt kezelt szennyezése, amely pusztán az idő múlásából eredően válhat aztán egyre nagyobb és kiterjedtebb volumenűvé. ${ }^{11}$ A szennyező fizet elve alapján kialakított felelősségi szabályokból'12 eredően nem volna szükségszerü, hogy mindezen kármentesítési feladatok az államra szálljanak, ugyanakkor az időben történő eredményes fellépés hiányában a piaci szereplők által kezelhetetlen nagyságrendűvé váló szennyezések sorsa végső soron és a gyakorlatban mégis ez. A hatékony állami fellépés hiányában a jövő generációkra pedig egyre több és nagyobb felhalmozódó környezeti adósságteher marad, ebben a megközelítésben tehát történeti károk a hátrahagyott, „megörökölt” környezeti károk mellett a jelen hatékony kezelés nélkül maradó olyan szennyezései is, amelyek aztán a gyakorlatban a már meglévő környezeti teherhez adódva növelik ezt az adósságterhet, válnak majd történeti kárrá.

A fenti időbeli és fogalmi meghatározásokon belül az állam szerepe és felelőssége többféleképpen megközelíthető. Ha a történeti károkat szűkebben értelmezzük, tehát mint a múltból eredő, ismert állami felelősségi körbe tartozó - egykori állami tevékenységből eredő, vagy az állami felelősségi körbe került - szennyeződéseket, akkor az állam a környezeti kármentesítési eljárás kötelezettje, és felelőssége is ehhez igazodik. E tekintetben az államnak nincsen kivételezett helyzete, kötelezettként az irányadó (hatósági) eljárások keretei közt kellene haladnia ezen feladataival. Mint már említettem, ez a gyakorlatban számos ok miatt ${ }^{13}$ nem érvényesül. Ha azonban a teljes idősíkot és fogalmi rendszert tekintjük, az államnak alaptörvényből levezetett alkotmányos felelőssége áll fenn mindezen - múltbéli, jelen és akár jövőbeli, a kármentesítésre kötelezett személyétől független - szennyezések és ebből eredő károk megelőzésének és kezelésének, a szennyezett területek használhatóságára is kiterjedő intézményesített rendszerének kialakítására és müködtetésére vonatkozóan.

A két megközelítés szigorúan nem választható el egymástól. A környezeti felelősség és a kármentesítés érvényesítésére is alkalmas hatékony állami intézményrendszer, illetve az alapját képező koherens jogi szabályozás és egyéb ösztönző

szempontrendszer alapján kidolgozott módszertan szerint rangsorolta, az OKKP éves és nyilvánosan elérhető beszámolási kötelezettségének az 1042/2008. (VI. 30.) Korm. határozat 1.39. pontjával történt megszüntetése és ténylegesen 2010 óta elmaradt közzétételével erről a rangsorolt pontos adat nem hozzáférhető.

${ }^{11}$ Az ún. chemical bomb effect, azaz „vegyi bomba hatás”.

${ }^{12}$ A hatályos szabályozásban a környezet védelmének általános szabályairól szóló 1995. évi LIII. törvény (Kvt.) 102. § (1) bekezdése alapján.

${ }^{13} \mathrm{Az}$ alapvető jogok biztosa és a jövő nemzedékek érdekeinek védelmét ellátó biztoshelyettes AJB-813/2012., valamint AJB-2030/2014. számú közös jelentései részletesen foglalkoztak a történeti károk kármentesítéseinek kérdéskörével. A jelentések megállapították, hogy az idő múlása, az akár évtizedekre indokolatlanul elhúzódó kármentesítések, az OKKP finanszírozásának fokozatos szűkülése és az arra vonatkozó éves beszámolási kötelezettség, valamint ebből eredően az adatok nyilvánosságának és hozzáférhetőségének hiánya mind-mind alapjogi visszásságot okoznak, és mind a Kormány, mind az akkori vidékfejlesztési miniszter felé intézkedést tettek az okok feltárása és a rendszerszintű problémák megszüntetése érdekében. 
eszközök alkalmazása nem csupán a már meglévő környezeti tehernek a helyreállítás elve mentén történő fokozatos csökkentése szempontjából fontosak, hanem a megelőzés elengedhetetlen eszközei is egyben. Általuk válnak a jövőbeni szennyezések elkerülhetővé vagy időben kezelhetővé. ${ }^{14}$

Eszközrendszerében és különösen finanszírozásában azonban a két megközelítés élesen eltér egymástól, mivel elöbbi a környezeti felelősség érvényesítésének rendszerével kapcsolatos állami szerepet, utóbbi a környezeti kármentesítésekben betöltött állami funkciót helyezi a középpontba. Míg a hátrahagyott történeti károk felszámolásához az állam föként saját forrásaira és apparátusára támaszkodva, elsődlegesen a helyreállítás elve mentén jár el, addig a jövőbeni károk esetén alapvető cél az elővigyázatosság és megelőzés, valamint a szennyező fizet elveinek maradéktalan érvényesítése - vagyis jóval inkább az, hogy az előbbi, a csakis állami helytállással és központi költségvetési forrásból finanszírozható kármentesítésre szoruló területek köre ne bővüljön. Utóbbi érdekében elsődleges szempont a piaci szereplők környezethasználatának „kordában tartása”, a preventív hatósági és egyéb eszközök alkalmazása és a mindezek ellenére esetlegesen szükséges kármentesítések forrását támogató biztosítékok rendszere..$^{15}$

A következő alpontban az állami felelősségi körbe tartozó, szükebb értelemben vett történeti károkról lesz szó, a vázolt idősíkon tehát a múltbéli, már ismert, kármentesítésre váró szennyeződések felszámolására tett eddigi intézkedésekről, öszszefoglalva az elmúlt évtizedek folyamatait és az azokból kirajzolódó irányvonalakat, következtetéseket.

\subsection{Az állam szerepe a történeti károk kialakulásában és kezeletlenségében}

Hazánkban a történeti károk kialakulása és az abban, illetve a jelenkori állapotokban az állami felelősség kérdésének vizsgálata elválaszthatatlan a történeti sajátosságoktól. A rendszerváltást megelőzően az állam felelőssége egyfelől mint tulajdonosé, másfelöl a nagy állami vállalatok tevékenységén keresztül mint környezethasználóé is megállapítható volt, amit az első vonatkozó szabályozások így is rendeztek. ${ }^{16}$

${ }^{14}$ A környezeti felelősség hatékony érvényesítésének rendszere, illetve annak a történeti károk felszámolására tett intézkedésekkel való összefüggései és különbözőségei részletesen kifejtésre kerültek a jövő nemzedékek érdekeinek védelmét ellátó biztoshelyettes jogalkotási kezdeményezésében a környezeti felelősség hatékonyabb érvényesítése érdekében, 2019. december. https://www.ajbh.hu/documents/10180/3157803/Jogalkotási_kezdeményezés_környezeti_felelősség/4821a1da-bb6b-8659-e97f-66f8b679c17d (2020. 11. 10.).

${ }^{15}$ Lásd erről bővebben a környezeti károk megelőzése és felszámolása tekintetében a Bizottság 2010-es jelentését, melynek 4. címe a pénzügyi biztosítékok rendszeréről szól. A Bizottság jelentése a Tanácsnak, az Európai Parlamentnek, az Európai Gazdasági és Szociális Bizottságnak és a Régiók Bizottságának a környezeti károk megelőzése és felszámolása tekintetében a környezeti felelősségről szóló 2004/35/EK irányelv 14. cikkének (2) bekezdése alapján, COM(2010) 581 végleges.

${ }^{16}$ A Kvt. hatálybalépését követő esetekben az annak 102. §-ában foglalt szabályozás érvényesült. A felszín alatti vizek minőségét érintő tevékenységekkel összefüggő egyes feladatokról szóló 33/2000. (III. 17.) Korm. rendelet 2004. augusztus 4-ig hatályban volt a 4. § (3) bekezdése értelmében, ha a tevékenység folytatója ismeretlen, vagy jogutód nélkül megszűnt, és ha a felszín alatti vizet, földtani közeget veszélyeztető, szenynyező vagy károsító, illetve az előírások megszegésével járó tevékenység a Kvt. hatálybalépését megelő- 
Az első felmérések - nem teljes körü tényfeltárások és számbavétel alapján mintegy 1000 milliárd forintra és 30-40 éves futamidőre becsülték a kármentesítések igényét. ${ }^{17}$ A gazdasági szerkezetváltás időszakában nem volt cél, hogy ezen kármentesítésekért az állam álljon helyt a központi költségvetés terhére, ezért a környezeti károk felszámolásáért privatizációs vagy adásvételi szerződésekben, jogutódlással vagy átvállalás útján új vállalkozások vállaltak kötelezettséget. Ezen jogviszonyokból befolyt összegek egy része - különösen a privatizáció bevételei pedig az egyéb kármentesítésre váró területek kezelésére fordítható központi keretet növelhette a kezdetekben. ${ }^{18}$

A vonatkozó általános eljárásrend szerint ${ }^{19}$ a hatóságok a szennyezett területek aktuális tulajdonosait kötelezték a kármentesítésre, „és ha már végképp nem tudtak a határozatoknak érvényt szerezni, vagy a vállalat jogutód nélkül megszünt, akkor került sor az állami felelősségi körbe való besorolás indoklására és felterjesztésére. (...) Olyan kármentesítési feladatok esetében, amelyben a hatóság más felelőst (gazdasági társaság, magánszemély, tárca) nem tudott megnevezni (például 1995. év elötti szennyezés) akkor a környezetvédelemért felelős miniszter lépett elő kötelezettként. Az Országos Környezeti Kármentesítési Program (OKKP) egyedi feladatainak meghatározása során alapvetően ez a vezérelv érvényesült. "20

Mivel tehát a környezeti kármentesítés elsősorban a múltbeli szennyezések által okozott környezeti károk mérséklésére, megszüntetésére vonatkozott, a kármentesítés feladata az államra hárult, amennyiben a szennyezés idejében nem létezett megfelelő jogi szabályozás, és a szennyező joghatályosan nem volt elérhető (tehát a szennyező fizet elv nem volt érvényesíthető). Bár számos esetben a feladatellátáshoz európai uniós forrás is rendelkezésre állt, ${ }^{21}$ az állami felelősségi körbe tartozó kármentesítéseknek az elsődleges finanszírozási forrása a Nemzeti Környezetvédelmi Program ${ }^{22}$ részét képező, 1996-ban indult OKKP volt. ${ }^{23}$ Az OKKP projektekre a központi költségvetésből 2012-ig évente allokáltak egy bizonyos összeget, önálló

zően történt, akkor a Magyar Állam nevében feladatkörébe és felelősségi körébe tartozóan a kormányzati munkamegosztás szerint felelős miniszter, illetve ha nincs más felelős, akkor a környezetvédelemért felelős miniszter által kijelölt szervezet volt kötelezett a kármentesítésre.

${ }^{17}$ Az egykori Észak-dunántúli Környezetvédelmi Felügyelőség archivált honlapjának OKKP-t bemutató oldala: http://edkvf.kvvm.hu/tartalom/vizved/fsza_okkp.html (2020. 11. 10.).

${ }^{18}$ Lásd Az alapvető jogok biztosa és a jövő nemzedékek érdekeinek védelmét ellátó biztoshelyettes AJB813/2012. számú közös jelentését.

${ }^{19}$ Kvt. 102. §, akkor hatályos 33/2000. (III. 17.) Korm. rendelet 4. § (3).

${ }^{20}$ A Nemzeti Fejlesztési Minisztérium OKKP Társasági Alprogram keretében a 2014-2020. programozási időszakban megvalósítani tervezett kármentesítési projektek stratégiai tervezése, KEOP-7.9.0/12-0037, vitaanyag, 2015. május.

${ }^{21}$ Az uniós csatlakozáskor az ún. kohéziós alapok jelentettek forrást a kármentesítésekhez. A Környezet és Energia Operatív Programban (KEOP) a 2004-2013 közötti időszakban több nagy projekt is lezajlott, illetve pályázati rendszer útján lehetett a forrásokat felhasználni. A 2014-2020 közötti időszakban a Környezeti és Energiahatékonysági Operatív Program (KEHOP), az önkormányzatok számára pedig a Területi és Településfejlesztési Operatív Program (TOP) nyújtott támogatásokat.

22 83/1997. (IX. 26.) OGY határozat a Nemzeti Környezetvédelmi Programról.

${ }^{23}$ A Kormány a 2205/1996. (VII. 24.) határozatával fogadta el a Kármentesítési Programot és a rövid távú szakasz (1996-1997) részletes feladatait. A középtávú szakasz (1998-2002) feladatairól a 2304/1997. (X. 8.) határozatával döntött. 
fejezeti előirányzatként. Az OKKP az állami felelösségi körbe tartozó kármentesítések ütemezett finanszírozását szolgálta, és egyidejüleg az olyan további károsodások megelőzését is támogatta, ahol ugyan volt felelős, de a környezeti károk megfékezése nem állt módjában. Azaz a környezeti felelösség érvényesítésének korlátai miatt az államnak kellett fellépnie annak érdekében, hogy a nagyobb és költségesebben kezelhető - feltehetőleg emiatt aztán úgyis az államra háruló - károkat elkerüljék. ${ }^{24}$

Fontos megjegyezni, hogy ebben az időszakban az OKKP mellett a környezeti felelősség hatékony érvényesítése - tehát nem elsődlegesen a történeti károk felszámolása - érdekében további alapok is müködtek. Így az 1990-ben létrehozott Központi Környezetvédelmi Alap (KKA), a Környezetvédelmi Alap Célelöirányzat (KAC), majd a Környezetvédelmi és Vízügyi Célelőirányzat (KÖVICE). A KKA bizonyos termékek - jó darabig egyebek mellett a kenőolaj és a benzin - árába épített termékdíjaiból befolyt komoly összegeket pályázati úton használták fel a kármentesítések területén is. 2000-ben a KKA a környezetvédelemért felelős minisztérium költségvetésébe került: ez volt a KAC, amely elöre meghatározott éves célok mentén alakította tovább a pályázati rendszert. A KÖVICE létrejötte már a környezetvédelem és a vízügy önálló megjelenítését jelentette, azonban 2004-ben ez is megszünt. Hazánk uniós csatlakozását követően a kármentesítési projektek finanszírozási forrását a már említett uniós kohéziós alapok is jelentették.

Mindezek alapján látható, hogy a közel 30-40 ezer nyilvántartott szennyezett területen ${ }^{25}$ a történeti károk kezelésére az OKKP eredeti koncepciójában egy ütemezett terv készült, évente átlagosan 20 milliárd forint forrásigényt jelölve meg. Az állami felelősségi körbe tartozó kármentesítés a kormányzati munkamegosztás szerint felelős miniszterek feladata volt, amiket az ún. OKKP tárca-alprogramok keretében folytattak.

Az OKKP végrehajtásának központi kormányzati felelőse a kezdetektől a környezet védelméért felelős miniszter volt, aki egyebek mellett gondoskodott az országos program müködtetéséről, az ehhez kapcsolódó jogi szabályozásokról, a tárcák kármentesítési alprogramjainak koordinációjáról, a szakmai irányításról, a tájékoztatásról, a szennyezett területek számbavételéröl és az ehhez kapcsoló informatikai rendszer fejlesztéséröl, müködtetéséről. ${ }^{26} \mathrm{Az}$ OKKP a céljaira allokált költségvetési források egyre gyorsabb ütemű csökkentését követően 2012-től már nem kapott önálló, a költségvetésben nevesített támogatást, az egyes kármentesítési feladatok ad hoc jellegü központi kormányzati döntések útján rendeződtek. ${ }^{27}$

\footnotetext{
${ }^{24}$ Az OKKP keretében végzett feladatok jogszabályi hátterét és a program végrehajtását a 33/2000. (III. 17.) Korm. rendelet, majd az azt felváltó, a felszín alatti vizek védelméről szóló 219/2004. (VII. 21.) Korm. rendelet és a földtani közeg és a felszín alatti víz szennyezéssel szembeni védelméhez szükséges határértékekről és a szennyezések méréséröl szóló 6/2009. (IV. 14.) KvVM-EüM-FVM együttes rendelettel hatályon kívül helyezett felszín alatti víz és a földtani közeg minőségi védelméhez szükséges határértékekröl szóló 10/2000. (VI. 2.) KöM-EüM-FVM-KHVM együttes rendelet biztosította.

${ }^{25}$ Az egykori Észak-dunántúli Környezetvédelmi Felügyelőség archivált honlapjának OKKP-t bemutató oldala: http://edkvf.kvvm.hu/tartalom/vizved/fsza_okkp.html (2020. 11. 10.).

${ }^{26}$ Az OKKP részletes feladatleírását az Országos Környezeti Kármentesítési Program előirányzat működtetésének és végrehajtásának általános szabályairól szóló 14/2009. (IX. 18.) KvVM utasítás tartalmazza.

27 Számos példa említhető a Kormány egyedi határozattal történő forrás teremtésére, így Abasár ivóvízbázisának szerves oldószerrel történt elszennyeződéséhez kapcsolódóan [a szennyezés feltárásához és az
} 
Megjegyzendő, hogy a ráfordítás az OKKP fennállása alatt egyetlen évben sem érte el az eredetileg tervezett összeget. 1994 és 2004 közt különböző állami forrásokból összességében több mint 80 milliárd forint ráfordítással közel 200 területen kezdődött meg a kármentesítés, ${ }^{28}$ míg 2016-ig, az addig eltelt húsz év során 580 állami felelősségi körbe tartozó intézkedést hajtottak végre közel 232 milliárd forint nagyságrendben. ${ }^{29}$ Mindez tehát a bevezetőben említett nehézségeknek a pénzügyi vetületű kihívásait mutatja. Napjainkra az előrejelzésekhez igazodó tervezett forrásfelhasználásról egyre kevésbé van szó. ${ }^{30}$

Az OKKP finanszírozásának helyzete azonban csak az egyik mutatója annak az intenzitás-csökkenésnek, ami az állam történeti károk felszámolására irányuló tevékenységét jellemzi. Ugyanez megmutatkozik a szervezetrendszeri átalakítások sürüsödésében és módjában is. ${ }^{31} \mathrm{~A}$ környezetvédelem önálló minisztériumi szinten történő központi kormányzati képviselete idején ${ }^{32}$ az OKKP-val kapcsolatos feladatok

ivóvízellátás biztosításához szükséges intézkedések költségeinek fedezéséről szóló 1817/2013. (XI. 14.) Korm. határozat, a szervesoldószer-szennyezettséggel kapcsolatos első kármentesítési lépések költségfedezetéről szóló 1524/2017. (VIII. 14.) Korm. határozat, valamint a károk helyreállításához és a tisztított víz hasznosításához köthető költségek viseléséről szóló 1283/2019. (V. 15.) Korm. határozat]; a Berhida Ipartelep szennyezett területek és az MH Ócsai üzemanyagraktár területén feltárt szénhidrogén szennyezettség kármentesítési projektjeinek támogatása [1335/2016. (VII. 4.) Korm. határozat]; vagy akár teljes alprogramok támogatásának biztosítása, így a Nemzeti Fejlesztési Minisztérium OKKP Társasági Alprogramhoz a 2014-2020 időszakban [1452/2013. (VII. 16.) Korm. határozat].

${ }^{28}$ Az egykori Környezetvédelmi és Vízügyi Minisztérium részben még elérhető honlapja: http://edkvf.kvvm.hu/ tartalom/vizved/fsza_okkp.html (2020. 11. 10.).

${ }^{29}$ A környezetügyért felelős helyettes államtitkár köszöntő beszéde a 2016. november 16-án, az Országos Környezeti Kármentesítési Program két évtizedes müködése alkalmából rendezett konferencián, a Herman Ottó Konferencia Központban: http://www.hermanottointezet.hu/node/800214 (2020. 11. 10.).

${ }^{30}$ A célra felhasznált összegek egységes és összesített kimutatása sem egyértelmü, hiszen változó, hogy összesített számról vagy csupán alprogramokról, esetleg a környezetvédelemért felelős miniszter felelősségi körébe tartozó projektekről van-e szó. A fentebbi adatokhoz képest a 2019. május 14-15-én a Környezetvédelmi Szolgáltatók és Gyártók Szövetségének Kármentesítés és Kárelhárítás Munkacsoportja által szervezett „Kármentesítés és barnamezős beruházások” nemzetközi konferencia kiadványában a következő bontásban szerepelnek az adatok: „Az OKKP alprogramok 2010-2017 között 110,9 Mrd Ft összeget kaptak a nemzeti költségvetésből, aminek felhasználásával több mint 300 területen történtek kármentesitési intézkedések. Az uniós források felhasználásával 2010-2014 időszakban 23 db ismert és már feltárt szennyezett területen történt eredményes kármentesitési beavatkozás a Környezeti és Energetikai Operatív Program (KEOP 2.4.0.) finanszírozásával (például Nyíregyháza, Rajka, Zirc, Ócsa, Taszár, Sármellék, Körösladány, Szolnok, Szeged, Eger stb.) 39,3 Mrd Ft értékben. A 2014-2020-as uniós programozási időszakban az állami vagyonkezelő szervezetek uniós támogatás felhasználására pályázhattak a Környezeti és Energiahatékonysági Operatív Program (KEHOP) hármas prioritásában, ahol 21,44 Mrd Ft került allokálásra a szennyezett területek állami felelősségi körbe sorolt kármentesítési intézkedéseinek ellátására (például Szekszárd Lőtérivízbázis, Esztergom Strázsa hegy, Peremarton, Berhida stb.). Az önkormányzatok részére a Területi és Településfejlesztési Operatív Program (TOP) kettes prioritás keretében 35,75 Mrd Ft állt rendelkezésre a városok belterületén hátrahagyott szennyezett és alulhasznosított barnamezős területek fejlesztésére." Kármentesítések és Barnamezős Beruházások Nemzetközi Konferencia, 8. https://kszgysz.hu/images/konferenciak/ karmentesites2019/karmentesites_konferencia_kiadvany_2019_hu.pdf (2020.11. 10.).

${ }^{31}$ Ez az elmúlt években folyamatosnak tekinthető szervezeti átalakítás természetesen nem csupán a kármentesítések helyzetét befolyásolta, hanem általában is a környezet- és természetvédelmi érdek képviseletének hatékonyságát a különböző szintű döntéshozatali mechanizmusokban.

32 1987: Környezetvédelmi és Vízgazdálkodási Minisztérium, 1990: Környezetvédelmi Minisztérium (a vízügyi igazgatás a Közlekedési, Hírközlési és Vízügyi Minisztériumhoz került), 1990. szeptember: Környezetvédelmi és Területfejlesztési Minisztérium, 1998: Környezetvédelmi Minisztérium, 2002: Környezetvédelmi és Víz- 
helye egyértelmü volt. Később, a Környezetvédelmi és Vízügyi Minisztérium 2010-ben történt megszünésével és a környezetvédelmi feladat- és hatásköröknek a vidékfejlesztési miniszterhez telepítésével, majd a háttérintézmények felállásával egyre követhetetlenebbé váltak az OKKP-val kapcsolatos feladatok ellátásának szervezeti szintjei.

Egy ponton „az OKKP-val kapcsolatos feladatok”33 a 2012. január 20-án létrejött Nemzeti Környezetügyi Intézethez (NeKI) kerültek. A NeKI alig 3 év után, 2015-ben jogutódlással megszűnt, beolvadt a Nemzeti Agrárszaktanácsadási, Képzési és Vidékfejlesztési Intézetbe (NaKVI), melynek során - névváltozással - létrejött a Herman Ottó Intézet (HOI). ${ }^{34}$ Utóbbi az OKKP-val kapcsolatos országos jelentőségü szakmai feladatokat, illetve a jogszabályokban a $\mathrm{HOI}$ feladataként nevesített egyedi kármentesítési feladatokat látta el. Mára nonprofit kft.-vé alakult. Jelenleg az OKKP alprogramjainak koordinációját, valamint az OKKP müködtetésével és végrehajtásával kapcsolatos tárcaközi szakmai feladatok előkészítését az Agrárminisztérium munkaszervezetén belül a környezetügyért felelős államtitkár alatt müködő Környezettechnológiai és Kármentesítési Főosztály végzi. ${ }^{35}$

Megjegyzendő, hogy az intézményrendszerre vonatkozó jogszabályi környezet, a telepített feladat- és hatáskörök megfogalmazásainak eltérései, történetileg a víz mennyiségi és minőségi védelmének fokozatos kettéválasztása számos esetben bizonytalanná tették, hogy a központi kormányzati munkamegosztásban a környezetvédelemért (és a vízügyért) felelős miniszter munkaszervezetében maradt felelős egységek és a háttérintézmények közt pontosan hogyan is alakul a feladatmegosztás és a felelösség kérdésköre, különösen az egyedi kármentesítési eljárások kötelezetti oldalán. ${ }^{36}$

Ezzel párhuzamosan a hatóság oldalán ugyancsak alakult a szervezetrendszer. 2015-ben, a vízügy kiválását követően a környezetvédelmi és természetvédelmi felügyelőségeknek a fővárosi és megyei kormányhivatalokba történő beépüléséről született döntés. ${ }^{37}$ A felügyelőségek átalakulásával a környezetvédelmi hatósági rendszer, illetőleg a kármentesítési eljárások lefolytatására hatáskörrel és illetékességgel rendelkező szervek köre is folyamatosan változott, ${ }^{38}$ ami értelemszerüen

ügyi Minisztérium, 2010: Vidékfejlesztési Minisztérium. Lásd bővebben: A hazai környezetügy - az elmúlt negyedszázadban. Tények és adatok, hazai előzmények és nemzetközi háttér. Az Országgyűlés Fenntartható Fejlődés Bizottsága, Budapest, 2013. http://real.mtak.hu/62438/1/Kornyezet25ev_OGy_u.pdf (2020. 11. 10.).

${ }^{33}$ A Nemzeti Környezetügyi Intézet alapító okiratának 11.1. pontja, valamint a környezetvédelmi, természetvédelmi, vízvédelmi hatósági és igazgatási feladatokat ellátó szervek kijelöléséről szóló 347/2006. (XII. 23.) Korm. rendelet 2014. január 1-jétől hatályon kívül helyezett 33/A. § i) pontja alapján, továbbá a 481/2013. (XII. 7.) Korm. rendelet 41. § 3. pontja alapján.

${ }^{34} \mathrm{Az}$ egyes állami feladatok átvételével kapcsolatos agrár- és környezetvédelmi tárgyú kormányrendeletek módosításáról szóló 147/2015. (VI. 12.) Korm. rendelet alapján.

${ }^{35}$ Az Agrárminisztérium Szervezeti és Működési Szabályzatáról szóló 10/2019. (XII. 30.) AM utasítás 4. címe.

${ }^{36}$ Lásd bővebben az alapvető jogok biztosa és a jövő nemzedékek érdekeinek védelmét ellátó biztoshelyettes AJB-813/2012. számú közös jelentését.

${ }^{37}$ A fővárosi és megyei kormányhivatalokról, valamint a járási (fővárosi kerületi) hivatalokról szóló 66/2015. (III. 30.) Korm. rendelet és a területi államigazgatási szervezetrendszer átalakításához kapcsolódó újabb intézkedésekről szóló 1744/2014. (XII. 15.) és 1195/2015. (III. 31.) Korm. határozatok alapján.

${ }^{38}$ A hatósági szervezetrendszerre vonatkozó alkotmányos értékelés szempontjairól lásd a jövő nemzedékek szószólójának a környezetvédelem szervezeti rendszerével kapcsolatos elvárásokról, különös tekin- 
szintén kihatott a folyamatban lévő eljárások elhúzódására. A szervezetrendszer folyamatos átalakításából eredően tehát a történeti károk felszámolására irányuló környezeti kármentesítési eljárásokban mind a kötelezetti oldalon, mind a hatóság oldalán huzamos ideje hiányzik a stabil, kiszámíthatóan és az adatok elérhetőségén keresztül transzparensen müködő, hatékony intézményrendszer. Mindezt egy olyan területen, ahol az eljárás lefolytatásában közvetlen érdekelt nincsen, a környezeti károk felszámolása a környezetvédelmi érdek mögötti kiemelt országos közérdek.

Ráadásul mindezen változásokat és azok konkrét eredményeit vagy hatásait egyre nehezebb nyomon követni. Az OKKP-val kapcsolatos beszámolási kötelezettség elmaradásával, ${ }^{39}$ a szervezeti átalakításokból eredően az intézményi memória elvesztésével, az ún. prioritási lista elérhetetlenségével nincsenek naprakész, a széles nyilvánosság számára hozzáférhető adatok. Mindeközben az államigazgatás egy másik ágában, az építésügyi vonalon megindult az ún. barnamezős területek, illetve még újabb jogintézményként az ún. rozsdaövezeti akcióterületek ${ }^{40}$ felmérése és hasznosítási kereteinek más szempontú meghatározása, mintegy függetlenül az eddigi évtizedes törekvésektöl és az OKKP egyre lassuló ütemű végrehajtásának egyre apadó forrásaitól.

\section{A történeti károk kezelésének államra vonatkozó alaptörvényi keretei}

Az állam „mérgezett örökségünk” adósságterhének csökkentésére, a történeti károk felszámolására tett törekvéseit éppen az elérhető és hiteles adatok hézagossága miatt nehéz értékelni. Különösen, hogy az OKKP a szennyező források folyamatos országos számbavételére is kiterjedt, és a beszámoló elmaradtával ennek üteme sem ismert. Az azonban bizonyos, hogy az Alaptörvény és a vonatkozó ágazati szabályozások, valamint az azok kereteit immáron alapjogi szempontból is értékelhetően ${ }^{41}$ meghatározó nemzeti ágazati koncepciók és stratégiák ${ }^{42}$ egyértelműen

tettel a hatósági szervezetrendszer kérdéseire szóló állásfoglalását, 2018. május. https://www.ajbh.hu/ documents/10180/2762244/Elvi_Állásfoglalás_Felügyelőségek_integrációja_2018.05.08.pdf/f7b76ffa-f01a3b8c-aaf0-ed6948efe5b7 (2020. 11. 10.).

39 Lásd a 10. lábjegyzetet.

${ }^{40}$ Az épített környezet alakításáról és védelméről szóló 1997. évi LXXVIII. törvény módosításaival bevezetett új jogintézmények. A barnamező fogalmát meghatározó rendelkezés 2019. július 8-án, míg a rozsdaövezeti akcióterületek hasznosítását célzó törvénycsomag 2020. július 22-én lépett hatályba.

${ }^{41}$ Az Alkotmánybíróság a nemzeti stratégiák kapcsán a 13/2018. (IX. 14.) AB határozatban kimondta: „Az egyes stratégiák a közjogi szervezetszabályozó eszközök körébe tartoznak, ennek megfelelően a kibocsátót kötik, ugyanakkor azonban a közép- és hosszú távú tervezés és kiszámítható jogalkotás olyan szakmai kiindulópontjai is egyben, melyek figyelembe vétele az elővigyázatosság és a megelőzés elveire is tekintettel különösen fontos az Alaptörvény P) cikk (1) bekezdésében nevesített, a nemzet közös örökségének körébe tartozó elemek esetében. Ennek megfelelően ezen szakmai tartalmú stratégiák figyelmen kívül hagyása valamely jogszabályváltozás alaptörvény-ellenességének vizsgálata során külön is értékelendő a nemzet közös örökségét érintő, és az Alaptörvény P) cikk (1) bekezdése szerint a jövő nemzedékek számára is megörzendő szabályozási tárgyak esetében." Indokolás [40].

42 27/2015. (VI. 17.) OGY határozat a 2015-2020 közötti időszakra szóló Nemzeti Környezetvédelmi Programról, 18/2013. (III. 28.) OGY határozat a Nemzeti Fenntartható Fejlődés Keretstratégiáról, és a következő alpont tekintetében az 1/2014. (I. 3.) OGY határozat a Nemzeti Fejlesztés 2030 - Országos Fejlesztési és Területfejlesztési Koncepcióról. 
tartalmazzák és levezethetővé teszik azon alkotmányos követelményeket, amelyek teljesülése immár vizsgálhatóvá válik.

Mindenekelött hangsúlyozandó, hogy az egészséges környezethez, valamint a testi és lelki egészséghez való alapvető jogok, ${ }^{43}$ valamint az Alaptörvényben a nemzet közös örökségének és a jövő nemzedékek érdekeinek védelmét deklaráló P) cikk, továbbá a nemzeti vagyonról szóló 38. cikk és az azokhoz füződő több évtizedes következetes, mind bővülő alkotmánybírósági gyakorlat ${ }^{44}$ árnyalja az állam alapvető életvédelmi kötelezettségét a környezeti kármentesítések területén, a sajátos tárgyhoz igazodóan helyezi azt kontextusba. Alapvető, az állam felé jelentkező követelmény tehát a humán egészségügyi kockázatok csökkentése, az emberi élet hosszú távú fennmaradását szolgáló ökológiai rendszerek, a környezeti elemek - különösen a földtani közeg és a vízkészlet - védelme, és a helyreállítás elve mentén a kármentesítések hatékony lefolytatása, valamint az ennek eléréséhez szükséges szabályozási és intézményi struktúra kialakítása.

Utóbbi kapcsán nem kerülhető meg az Alkotmánybíróság egészséges környezethez való alapvető joggal kapcsolatos gyakorlatát máig megalapozó 28/1994. (V. 20.) $A B$ határozat és az abban kifejtett ún. objektív intézményvédelmi kötelezettség: „A környezetvédelemhez való jog mindezekkel szemben elsősorban önállósult és önmagában vett intézményvédelem, azaz olyan sajátos alapjog, amelynek az objektív, intézményvédelmi oldala túlnyomó és meghatározó. A környezethez való jog az állam környezetvédelemre vonatkozó kötelességei teljesítésének garanciáit emeli az alapjogok szintjére, beleértve a környezet elért védelme korlátozhatóságának feltételeit is. E jog sajátosságai folytán mindazokat a feladatokat, amelyeket másutt alanyi jogok védelmével teljesít az állam, itt törvényi és szervezeti garanciák nyújtásával kell ellátnia." Az állam szabadságot élvez abban, hogy ezeket a szabályozási és intézményi garanciákat hogyan alakítja, ugyanakkor a védelem szintje nem tetszőleges. A visszalépés tilalmának elvéből eredően azt nem csökkentheti, kivéve, ha ez más alapjog vagy alkotmányos érték elérése érdekében elkerülhetetlen, ám ekkor is szem elött tartva a szükségesség-arányosság követelményét. ${ }^{45}$

Megjegyzendő, hogy a szervezetrendszeren belül a hatósági rendszer müködése visszacsatolási forrás is egyben a (központi) döntéshozatal számára, az ugyanis tevékenysége során elengedhetetlen adatforrást képez. A pontos adatok léte, a nyilvántartások naprakészsége és elérhetősége a fentiek előfeltétele: a környezet állapotának és terhelésének ismerete nélkül nem határozható meg a célok és az azok eléréséhez - a szennyezettség felszámolásához, a vízkészletek hatékony menynyiségi és minőségi védelméhez - szükséges eszközrendszer, sem finanszírozási, sem intézményes, sem egyéb szempontból.

A környezeti kármentesítés és azon belül az OKKP célja az elmúlt évszázadban a földtani közegben és a felszín alatti vizekben hátramaradt, akkumulálódott szeny-

${ }^{43}$ Alaptörvény XX. cikk (1) Mindenkinek joga van a testi és lelki egészséghez. XXI. cikk (1) Magyarország elismeri és érvényesíti mindenki jogát az egészséges környezethez.

${ }^{44}$ Az Alkotmánybíróság visszalépés tilalmával és az állam objektív intézményvédelmi kötelezettségeivel foglalkozó határozatai közül a témakörrel kapcsolatosan kiemelendő a 16/2015. (VI. 5.) AB határozat, a 13/2018. (IX. 4.) $A B$ határozat, a 4/2019. (III. 7.) AB határozat, valamint legutóbb a 14/2020. (VII. 6.) AB határozat.

45 Lásd az Alaptörvény I. cikk (3) bekezdését. 
nyezettségek felderítése, mértékük feltárása, a szennyezett területeken a szennyezettség mérséklése vagy megszüntetésének elősegítése, a sérülékeny területeken a szennyezettség kockázatának csökkentése vagy megszüntetése. ${ }^{46} \mathrm{~A}$ víz az élet alapja, talán legértékesebb véges javunk. Hazánk ivóvízellátása 94\%-ban a felszín alatti vízkészletekből történik. ${ }^{47} \mathrm{~A}$ vízkészlet és a természeti környezet állapota a klimatikus viszonyok bonyolult ökológiai összefüggésein és hálózatain keresztül kölcsönösen kihatnak egymásra. Közvetlen az összefüggés tehát a vízkészletek védelme és a fentebb említett alapvető jogok, valamint a jövő nemzedékek érdekeinek védelme közt: előbbi egyfajta előfeltétele utóbbiak érvényesülésének, érvényesíthetőségének. Az állam alapvető feladata tehát ezen a jelen és jövő generációk számára kritikus területen a szabályozási és szervezetrendszeri átalakítások során a folyamatos és kiemelt mennyiségi és minőségi vízbázis-védelem biztosítása.

Az Alaptörvény 38. cikke értelmében „az állam és a helyi önkormányzatok tulajdona nemzeti vagyon. A nemzeti vagyon kezelésének és védelmének célja a közérdek szolgálata, a közös szükségletek kielégítése és a természeti erőforrások megóvása, valamint a jövő nemzedékek szükségleteinek figyelembevétele." Az állam alkotmányos felelőssége tehát nem csupán mint a feladat- és hatásköréhez rendelten sajátos eszköztárral rendelkező közjogi személy felelőssége vizsgálható, hanem a nemzeti vagyon tulajdonosaként is, a vízkészlet ugyanis jellemzően kizárólagos állami tulajdonban áll. ${ }^{48}$ „Ekképpen az állam felelőssége a társadalom felé - ideértve a jövő nemzedékek tagjait is - kettős tartalmat hordoz, egyrészt az Alaptörvény által biztosított jogok védelmezője, másrészt tulajdonos, illetve még pontosabban, a nemzet közös örökségét képező közjavak kezelője. (...) A tulajdonos állam P) cikkből fakadó hármas kötelezettségének tartalmát erősíti, illetve a nemzeti vagyon tekintetében mintegy kibontja az Alaptörvény 38. cikke."49

$A z$ Alaptörvény $P$ ) cikke a tulajdonosi feladatkörben is értelmezhetően ún. egyetemes hármas kötelezettséget állapít meg a jövő nemzedékek felé: „a természeti erőforrások, különösen a termöföld, az erdők és a vízkészlet, a biológiai sokféleség, különösen a honos növény- és állatfajok, valamint a kulturális értékek a nemzet közös örökségét képezik, amelynek védelme, fenntartása és a jövő nemzedékek számára való megőrzése az állam és mindenki kötelessége". ${ }^{0}$ Az Alkotmánybíró-

${ }^{46} 33 / 2000$. (III. 17.) Korm. rendelet a felszín alatti vizek minőségét érintő tevékenységekkel összefüggő egyes feladatokról, 4. § (5).

${ }^{47}$ Magyarország ivóvízminősége, 2017. ÁNTSZ, Budapest, 2019. 4. https://www.antsz.hu/data/cms90078/ Ivovizminoseg2017_v2.pdf (2020. 11. 10.). A felszín alatti víz alatt értendő a kimutatás szempontjából a nyersvíz eredete szerint a felszín alatti víz, a parti szürésű, illetve az egyéb (termál, karszt) víz is.

${ }^{48}$ A nemzeti vagyonról szóló 2011. évi CXCVI. törvény 4. § (1) bekezdés d) pontja értelmében az állam kizárólagos tulajdonában állnak „a felszín alatti vizek természetes víztartó képződményei, a folyóvíz és természetes tavak elhagyott medre és a folyóvízben, természetes tavakban újonnan keletkezett sziget, valamint az 1. mellékletben meghatározott folyóvizek, holtágak, mellékágak, természetes tavak és ezek medre".

${ }^{49} \mathrm{Az}$ alapvető jogok biztosa a jövő nemzedékek érdekeinek védelmét ellátó biztoshelyettesének állásfoglalása az Alkotmánybíróság számára a T/384. számú, a vízgazdálkodásról szóló 1995. évi LVII. törvénynek a vízkivételekkel összefüggő módosításáról szóló törvény előzetes normakontrolljához kapcsolódóan: http://public. mkab.hu/dev/dontesek.nsf/0/cbb2386065131e71c12582da004720cb/\$FILE/I_1216_6_2018_allasfoglalas_ anonim.pdf (2020. 11. 10.). Vö. 13/2018. (IX. 4.) AB határozat, Indokolás [54].

${ }^{50}$ Alaptörvény $\left.\mathrm{P}\right)$ cikk (1). 
ság gyakorlatában kifejtettek szerint a védelem, fenntartás és megőrzés hármasából a megőrzés kötelezettsége tovább bontható: „A természeti erőforrások jövő nemzedékek számára történő megőrzésével összefüggésben pedig a jelen generációt a választás lehetőségének megörzése, a minőség lehetőségének megörzése és a hozzáférés lehetőségének megörzése terheli. (...) A nemzet közös örökségébe tartozó vagyontárgyakkal való felelős gazdálkodás egyik Alaptörvényben nevesített célja, nevezetesen a jövő nemzedékek szükségleteinek meghatározása nem politikai kérdés, azt mindenkor tudományos igénnyel lehet és kell meghatározni, az elövigyázatosság és megelőzés elvének érvényesülésére is figyelemmel.'51

Azok az alkotmányos keretek tehát, amelyek az állam szerepét és ehhez igazodóan a müködését a környezeti kármentesítésekhez kapcsolódóan meghatározzák, több oldalról is megközelíthetőek. Bármely oldalról is vizsgáljuk azonban a kérdést, az állam a történeti károk felszámolásával „adós” marad. A kiemelt közérdek érvényesítése, az OKKP - vagy bármely más, a visszalépés tilalmából eredően legalább az OKKP szintjét biztosító program vagy egyéb eszköz - müködtetése és végrehajtása alkotmányos kötelezettsége. Ennek elmaradása és mind további elhúzódása a fenti összefüggésekből eredően, a szennyeződések „láthatatlan”, földfelszín alatti és észrevétlenül terjedő, kumulálódó és akár eszkalálódó jellegéből adódóan az alapjogok érvényesülésének és a $\mathrm{P}$ ) cikkben megfogalmazott államcél elérésének gátját, illetve ennek kockázatát jelentheti.

\section{A rozsdaövezeti akcióterületek új jogintézménye az állam kármentesítésekkel kapcsolatos alkotmányos felelősségének tükrében}

\subsection{A rozsdaövezeti akcióterületek fogalma, a szennyezett területek hosszú távú területhasználati módjainak kijelölése}

A városi szövetbe ékelödő, korábbi környezethasználatok miatt elszennyezett és elhagyatott területek újrahasznosítása, bevonása a település vérkeringésébe nem újkeletü igény. Számos sikeres nemzetközi és hazai mintaprojekt ${ }^{52}$ mutatja, hogy ezeket az egyébként rendkívül értékes települési terület-tartalékokat érdemes számba venni, és azokat megfelelő módon és rendeltetéssel ismét életre lehet kelteni. Magyarország lakosságának több mint $70 \%$-a már ma városi vagy városias környezetben él, de a hazai népesség mozgásával kapcsolatos nemzetközi előrejelzések ennek az aránynak a további növekedését vetítik elöre. Azaz a városi és az agglomerációs területek népessége várhatóan tovább növekszik, míg a vidék néptelenedik. ${ }^{53}$ Kiemelten fontos tehát az élhető és fenntartható városi környezet megteremtése, az említett területek pedig kiválóan alkalmasak lehetnek rendelte-

51 13/2018. (IX. 4.) AB határozat, Indokolás [13] és [15].

${ }^{52}$ Előremutató hazai példaként említhető a volt Óbudai Gázgyár felhagyott területén megvalósult Graphisoft Park fejlesztése. Az 1997-ben kezdett projektben mára $82000 \mathrm{~m}^{2}$ hasznos alapterületű iroda, labor és oktatási terület több mint ötezer munkatársat és közel ezer diákot szolgál. https://www.graphisoftpark.hu/hu (2020. 11. 10.).

${ }^{53} \mathrm{http}: / /$ nepesseg.com/ (2020. 11. 10.). 
tésükben kompakt egységet létrehozó, a munkahelyek, lakások és szolgáltatások közelségét megteremtő településrészek kialakítására.

A történeti károk felszámolásának alkotmányos kereteivel összhangban a nemzet közös örökségének és a jövő nemzedékek érdekeinek védelme szempontjából kiemelt jelentőséggel bír az is, hogy alkalmasságuk függvényében inkább ezek a (megfelelö előkészületeket követően fejleszthető) területek kerüljenek beépítésre, semmint az értékes, aktív ökológiai szolgáltatást nyújtó „zöldmezők” - értve itt ez alatt a nemzet közös örökségének részét képező, különösen és kiemelten értékes erőforrásunkat, a termőföldet is. Mindez monetárisan is értékelhető szempont, azaz gazdasági érdek is füződik ennek következetes érvényesítéséhez. Ugyanakkor alapvető követelmény, hogy mindezen elöremutató koncepciók megvalósítása során is érvényesüljenek az alaptörvényi kereteket biztosító eljárási és egyéb szabályozási és intézményi garanciák. A kármentesítési célállapot elérése még nem feltétlenül jelenti azt, hogy az adott területen bármely funkció korlátozás nélkül elhelyezhető volna, a környezet- és humán egészségügyi kockázatokat minden esetben komolyan és felelösen szükséges mérlegelni. ${ }^{54}$

A szóban forgó területek hasznosításának gondolata egy ideje jelen van a szakmai és kormányzati elképzelésekben. ${ }^{55} \mathrm{~A}$ jogalkotó elsőként a „barnamezős terület” fogalmát vezette be az épített környezet alakításáról és védelméről szóló 1997. évi LVIII. törvénybe (Étv.) 2019 nyarán. Eszerint az „olyan földrészlet vagy földrészletek összessége - ide nem értve a mezö- és erdőgazdasági területeket -, amely elsősorban ipari, kereskedelmi, közlekedési vagy honvédelmi célú felhasználást követően felhagyottá, alulhasznositottá vagy leromlott állapotúvá vált, jellemzően környezetszennyezéssel terhelt, ugyanakkor környezeti és müszaki beavatkozással értéknövelt, fejleszthetö területté alakitható". ${ }^{56} \mathrm{~A}$ települési önkormányzatok egyidejüleg 2021. december 31-ig kaptak határidőt arra, hogy ezeket a területeket a településrendezési eszközeikben lehatárolják, illetve azok lehetséges fejlesztési irányait a településfejlesztési dokumentumaikban - a településfejlesztési koncepcióban és az integrált településfejlesztési stratégiában - meghatározzák. ${ }^{57}$

Mindazonáltal a barnamezős területek bevezetését követően alig egy évvel újabb sajátos jogintézmény jelent meg a jogrendszerben: a rozsdaövezeti akcióterület, amely létrehozásához törvénymódosító csomagot alkotott az Országgyűlés.$^{58} \mathrm{Az}$ Étv.

\footnotetext{
${ }^{54} \mathrm{~A}$ „megtisztított” területek funkcióinak lehetőségeiről lásd PAULIK Katalin: Remediáció ésszerüen. Beszélgetés Gondi Ferenc geológussal. Innotéka, 2017. november. https://www.innoteka.hu/cikk/remediacio_eszszeruen.1602. html (2020. 11. 10.).

552019 májusában a Környezetvédelmi Szolgáltatók és Gyártók Szövetségének Kármentesítés és Kárelhárítás Munkacsoportja szervezett nemzetközi konferenciát „Kármentesítés és barnamezős beruházások” címmel. https://kszgysz.hu/re-brown (2020. 11. 10.).

${ }^{56}$ Étv. 2. § 43. pont. Bevezette az egyes törvényeknek az épített és a természeti környezet védelmével, valamint a kulturális örökségvédelemmel összefüggő módosításáról szóló 2019. évi LXIV. törvény 7. §-a.

57 Étv. 8. § (7); 60. § (9).

${ }^{58}$ A rozsdaövezeti akcióterületek létrehozásához szükséges intézkedésekről szóló 2020. évi LXXVII. törvény az Étv.-n kívül a nemzetgazdasági szempontból kiemelt jelentőségű beruházások megvalósításának gyorsításáról és egyszerüsítéséről szóló 2006. évi LIII. törvényt (Ngtv.), valamint az általános forgalmi adóról szóló 2007. évi CXXVII. törvényt (Áfatv.) módosítja, illetve sajátosságokat állapít meg a felszín alatti vizek védelméről szóló 219/2004. (VII. 21.) Korm. rendelet egyes, hatósági eljárásra vonatkozó szabályaira.
} 
módosítása egy újabb olyan kategóriát hozott létre, amelyben a Kormány kijelölésétől függően, akár építési telek szinten egyedi beépítési szabályok érvényesülhetnek. ${ }^{59}$ Ezzel a kijelölt területek minden szempontból versenyképessé válhatnak a beruházók számára.

Az Étv. fogalommeghatározásai közé felvett definíció értelmében rozsdaövezeti akcióterület a „kormányrendeletben kijelölt, közlekedési, közmü- és intézményi infrastruktúrával ellátott vagy fenntartható módon ellátható, lakó- és más rendeltetés kialakitására alkalmas, jellemzően barnamezős területeket is magában foglaló terület, függetlenül attól, hogy a barnamezős területek (...) lehatárolása megtörténte". ${ }^{60}$ Megkülönböztethetünk azonnali, illetve közép- és hosszú távú rozsdaövezeti akcióterületeket, annak függvényében, hogy az azokon megvalósítani kívánt építési beruházásokhoz szükséges előkészítő munkálatok - értve ezek alatt a környezeti kármentesítéseket is - szükségesek, vagy sem, folyamatban vannak, és belátható időn belül befejezhetőek, vagy sem, illetve, hogy a tervezett beruházói szándék mennyire komoly; előkészítés vagy engedélyezés alatt áll-e már az építési tevékenység, illetve annak mielőbbi kezdését a rozsdaövezeti kedvezmények gyorsíthatják-e. A történeti károkkal szennyezett területek tekintélyes része feltehetőleg a közép- és hosszú távú rozsdaövezeti akcióterület kategóriába sorolható, hiszen ezeken a környezeti kármentesítés, bontás, közmürendezés és infrastruktúra-fejlesztés, tulajdonrendezés, telekalakítás és településrendezési feladatok elvégzése még mind-mind szükséges lehet. Ezek időtartama pedig szinte kiszámíthatatlan, és jellemzően kormányzati koordinációt és jelentős anyagi ráfordítást igényelnek. ${ }^{61}$

A rozsdaövezeti kijelölés joghatásának lényege, hogy az akcióterületen az előkészítő munkálatokhoz szükséges beruházás (így a kármentesítés is), illetve a területen megvalósítandó építési vagy egyéb beruházás automatikusan nemzetgazdasági szempontból kiemelt jelentőségű, kiemelten közérdekű beruházásnak minősül. ${ }^{62}$ Az Étv. deklarálja, hogy a rozsdaövezeti akcióterületek újrahasznosítása, azoknak akár lakhatási feltételek biztosítására alkalmassá tétele számos vetületben - környezet- és természetvédelem, egészséges lakó- és munkakörülmények - kiemelten fontos közérdekű cél. ${ }^{63}$

\footnotetext{
${ }^{59}$ Az Étv. 4. § (3a) bekezdése alapján öt esetkörben van erre lehetősége a Kormánynak: „A magyar történelem kiemelkedő jelentőségü helyszínein lévő, a nemzeti vagyonról szóló törvény szerint az állam kizárólagos tulajdonába tartozó építmények vagy nemzetgazdasági szempontból kiemelt jelentőségü nemzeti vagyonnak minősülő müemlékek és müemlékegyüttesek, valamint a nemzetgazdasági szempontból kiemelt jelentőségü beruházások megvalósításának gyorsításáról és egyszerüsítéséről szóló 2006. évi LIII. törvény szerint nemzetgazdasági szempontból kiemelt jelentőségű beruházás során építési tevékenységgel érintett telekre, valamint az országos jelentőségü kulturális és sport rendeltetésü építmények telkére, valamint az azok közvetlen környezetébe tartozó telkekre vonatkozóan az ott megvalósítandó közérdekü beruházás érdekében, valamint a nemzetbiztonsági célú építmények telkére vonatkozóan a Kormány rendeletben megállapíthatja a beépítés szabályait, az egyedi építési követelményeket és a területrendezési szabályokat.” A területfejlesztésről és területrendezésről szóló 1996. évi XXI. törvény 8. §-a alapján mindezen esetekben a Kormány „egyedi, az országos, a kiemelt térségi és a megyei területrendezési terv rendelkezéseitől eltérő vagy annak alkalmazását kizáró területrendezési szabályokat és különös hatósági eljárási szabályokat" is megállapíthat.

60 Étv. 2. § 45. pont.

${ }^{61}$ Étv. 2. § 47. pont.

${ }^{62}$ A 2006. évi LIII. törvény egyidejü módosításával annak hatálya alá tartoznak, illetve Étv. 4/A. § (2).

63 Étv. 4/A. § (1).
} 
Az adózási szabályok módosítása mellett ${ }^{64}$ ez lehet az egyik legnagyobb ösztönző a beruházók számára, a nemzetgazdasági szempontból kiemelt beruházások esetén ugyanis sajátos hatósági eljárásrend az irányadó. A kiemelten közérdekủ beruházások a nemzetgazdasági szempontból kiemelt jelentőségủ beruházások közt is egy külön kategória, amelyekben a beruházás megvalósításához füződő kiemelt közérdek még további „kedvezményeket”, egyszerüsítést és gyorsítást tesz lehetővé. ${ }^{65}$

A barnamezős és rozsdaövezeti akcióterületek tehát éppen olyan területek, amelyek a történeti károk helyszínei. Ugyanakkor az Étv. szabályozási igénye alapján kiviláglik, hogy bár a gyakorlatban a területhasználati módok meghatározásának a szennyezések nyilvánvaló korlátokat szabtak, azok mindeddig nem jelentek meg hivatalosan az építésügyben az országos szinttöl a települési szintig terjedő tervrendben. ${ }^{66}$ Sőt, ezen tervrend csúcsán az országos közérdeket megtestesítő új országos és kiemelt térségi területrendezési terv ${ }^{67}$ számos, ebből a szempontból lényeges tervlapot kivezetett a törvényi szabályozásból. ${ }^{68}$

$E$ kettő összefüggése és elválaszthatatlansága pedig alapvető; azé ugyanis, hogy egy adott terület milyen mértékben szennyezett, és a kármentesítéssel elérhető eredményhez képest ott milyen funkció helyezhető el, illetőleg fordított irányból, hogy a hosszú távú, településtervezési szempontból meghatározott területhasználat milyen mértékú beavatkozást igényel az adott területen. Az e tekintetben adódó ellentmondás az első bizonytalansági tényező: a két lehatárolás egymástól való függetlensége. Elöfordulhat ugyanis, hogy egy, a Kormány által az önkormányzat közigazgatási területén kijelölt rozsdaövezet egyben a helyi településrendezési eszközben felmért barnamezős területként is szerepel, ugyanakkor annak vonatkozásában a helyi szabályozások a Kormány kijelölése miatt nem fognak érvényesülni.

Ezen ellentmondástól függetlenül a kijelölés alapja úgyszintén problematikus, hiszen feltételezi éppen azokat a tényezőket, amelyek a történeti károk felszámolására irányuló tevékenység alapjogi kereteiből adódnak: mindenekelőtt az OKKP végrehajtását, a szennyező forrásoknak és az azok jelentette humán és egyéb ökológiai kockázatok mértékének ismeretét, valamint nem utolsósorban a vízkészlet védelme érdekében a megtisztított területen kijelölhető területhasználatokat. A prioritási lista tárgya szerint a rozsdaövezeti azonnali és közép- és hosszú távú besorolások alapja is. Naprakész adatok hiányában a települések barnamezős területeinek a leha-

${ }^{64}$ Az Áfatv. módosításának lényege, hogy az építőipari kereslet biztosítása érdekében az olyan, rozsdaövezeti akcióterületeken épülö többlakásos lakóingatlanban kialakítandó vagy kialakított, $150 \mathrm{~m}^{2}$-t meg nem haladó összes hasznos alapterülettel rendelkező új lakások értékesítésére, amelyek első rendeltetésszerű használatbavétele még nem történt meg, vagy annak megtörténtétől az értékesítéséig 2 év még nem telt el, kedvezményes, $5 \%$-os áfakulcsot vezet be.

${ }^{65}$ Ngtv. 11-11/G. §, a 11/B. § (7) szerint a kármentesítési eljárások határideje egységesen 42 nap.

${ }^{66}$ A tervrendet az OTrT. 3. §-a, az Étv. 8. § (1) bekezdése és a településfejlesztési koncepcióról, az integrált településfejlesztési stratégiáról és a településrendezési eszközökröl, valamint egyes településrendezési sajátos jogintézményekről szóló 314/2012. (XI. 8.) Korm. rendelet 4. §-a biztosítja.

${ }^{67}$ Magyarország és egyes kiemelt térségeinek területrendezési tervéröl szóló 2018. évi CXXXIX. törvény (OTrT.).

68 Így a korábban hatályos, a Balaton Kiemelt Üdülökörzet Területrendezési Tervének elfogadásáról és a Balatoni Területrendezési Szabályzat megállapításáról szóló 2000. évi CXII. törvényben a kiemelten érzékeny felszín alatti vízminőség-védelmi terület övezete is szerepelt. 
tárolása egy újabb felmérési, számbavételi feladat is, és ebben az esetben egyben annak elismerése, hogy a települési szintű lehatárolás jelenleg ebben a formában alkalmazhatóan nem, vagy nem így áll rendelkezésre. Mindezen építésügyi feladatok forrásigénye azonban nem úgy jelentkezik - és nem is úgy követhető nyomon -, ahogyan az OKKP finanszírozása.

A környezeti kármentesítés ${ }^{69}$ egy folyamat - jogi vetületben hatósági eljárás -, amelyben számos tényező elöre nem ismert. A beavatkozásokhoz szükséges anyagi ráfordítás mértéke jelentősen, akár nagyságrendileg változhat a tényfeltárást követően, vagy akár utólag, a monitoring eredményeinek ismeretében. A gyakorlatban a rozsdaövezeti azonnali besorolás szempontjából például műszaki előfeltétel lehet, hogy a monitoring kút alacsony koncentrációt mutat, azonban ez a folyamat jellegéből adódóan hosszabb időtávon változhat is. Ezt a természettudományos elemet a szabályozás nem tudja „kiiktatni”, legfeljebb megfelelően és hatékonyan kezelni, mindenkor szem előtt tartva az emberi egészségre gyakorolt hatások kockázatát.

Mindezeket figyelembe véve kiemelkedő jelentőséggel bír, hogy a kijelölésben a Kormány a felszín alatti vizek és a földtani közeg kármentesítésével összefüggő hatósági eljárások ágazati jogszabályaiban foglaltaktól eltérő különös eljárási szabályokat, a kármentesítés során a tényfeltárás, a beavatkozás és a kármentesítési monitoring egyedi szabályait is megállapíthatja. ${ }^{70}$

\subsection{Fennmaradó kérdések és következtetések a történeti károk és a rozsdaövezeti akcióterületek viszonylatában}

Tekintve, hogy a szóban forgó kormányzati kijelölések még nem történtek meg, annak vizsgálata, hogy ezek mennyiben jelentenek majd az általánostól eltérő szabályokat és milyen alkotmányos eljárási vagy egyéb garanciák veszhetnek el, még nem lehetséges. Számos egyéb kérdés azonban felmerül. Így az, hogy milyen eljárással és hogyan jelölik ki az adott területeket, és ez hogyan viszonyul a folyamatban lévő kármentesítésekhez, a történeti károk felszámolásához, illetve az OKKP végrehajtásához? Úgy tünik, az építésügyi ágazati jogalkotás az immáron negyedszázados folyamatokra utalás nélkül, látszólag azoktól függetlenül született. ${ }^{71}$

Milyen felelösségi szabályok kapcsolódnak a kijelöléshez, a lehatároláshoz, a kármentesítés eredményéhez, különös tekintettel az érintett területen meghatározott

${ }^{69}$ A kármentesítési eljárások részletes szabályait a felszín alatti vizek védelméről szóló 219/2004. (VII. 21.) Korm. rendelet szabályozza. A tényfeltárási szak alapján készül el a beavatkozási terv, annak végrehajtását követően a monitoring szakban folyamatosan ellenőrizni szükséges, hogy a beavatkozás az előzetesen kitüzött célállapotot tartósan elérte-e.

${ }^{70} \mathrm{Ngtv}$. 11/B. $\S(1)$ bekezdés $f$ ) pont és (7) bekezdés.

${ }^{71}$ A vonatkozó új, módosító törvénycsomag előterjesztési szakában a T/10746. számú javaslat indokolása egyáltalán nem tartalmazott utalást a kármentesítésekre vagy a szennyezett területekkel kapcsolatos eddigi tevékenységekre, és céljaként „a gazdaságélénkités, a városi rozsdaterületek túlsúlyával jellemezhető övezetek fejlesztésének elösegitése a lakásépitések támogatásával, valamint hosszabb távon a városi jelentöségü rozsdaövezeti akcióterületek fejlesztésre történő elökészítése” jelenik meg. https://www.parlament.hu/ irom41/10746/10746.pdf (2020. 11. 10.). 
lehetséges területhasználati módokra? Az építésügyi ágazatban az engedélyköteles tevékenység jelentős szűkítésével a felelősséget az építtető, kivitelező és tervező hármasa viseli. ${ }^{72}$ Kiemelten fontos ennek tudatosítása, a szabályok és az alkalmazásuk, alkalmazhatóságuk átláthatósága.

A rozsdaövezeti akcióterületek létrehozásáról szóló törvénycsomag mindezen kérdéseket nyitva hagyja, jóllehet ezek az alapjogi keretek vizsgálatának is elöfeltételei: szükségesek annak megítéléséhez, hogy ebben az új jogintézményben mennyiben érvényesülnek az egészséges környezethez és a testi-lelki egészséghez való alapvető jogok, a nemzet közös örökségének és a jövő nemzedékek érdekeinek védelme, és mennyiben, hogyan jelent akár előre-, akár visszalépést a korábbi szabályozáshoz képest e tekintetben. Az alapvető kérdés az, hogy az új megoldás alkotmányos keretek közti hatékony katalizátora lesz-e elakadt folyamatoknak, esély a történeti károk felszámolására, egyebek mellett egy új „érdekelti fél” - a szennyezett területen beruházni kívánó vállalkozás - bevonzásával, vagy a fejlesztési szemlélet és a bürokrácia-csökkentés jegyében aránytalan és szükségtelen kockázatot megvalósító korlátozás lesz?

A kérdés megválaszolásához elengedhetetlen leszögezni, hogy „(n)em vitatott az az állami igény, hogy a különböző támogatásokból megvalósuló egyes beruházásokat gyorsabban, követhetö módon bonyolítsák le, ugyanakkor a gyorsaság és az eljárás egyszerüsítése nem mentesíti az államot a P) cikkböl, valamint a 38. cikkböl fakadó alaptörvényi kötelezettségei alól. Emellett a kiemelt kezeléshez füződő jogos érdekeket össze kell hangolni, egyensúlyba kell hozni a környezet- és természetvédelem vagy a kulturális örökségvédelem szempontrendszerének egészével. Nem feledkezhetünk meg arról, hogy minden olyan lépés, amely nem kellöen mérlegeli az eltérő szempontokat, egyben hátrányosan érinti a jövő nemzedékek érdekeinek védelmét is. (...) Minden kivétel, amely az általános szabályoktól való eltérés megengedésével enyhíti a szabályokat, magában hordozza a környezet védelmére létrejött rendszer egésze gyengitésének veszélyét." ${ }^{73}$

Az állam alkotmányos felelőssége körében már felmerült, hogy az nem csupán a közjogi személy felelősségeként közelíthető meg, hanem mint tulajdonosé is. A fentebbi, a visszalépés tilalmát is felvető kérdéseken túl felmerül az is, hogy a „felelös és rendeltetésszerü" ${ }^{4}$ gazdálkodás követelményének mennyiben felel meg, ha a tulajdonos - az állam - egy immáron több évtizedes és rendkívül költséges rendszer adatainak, eredményeinek és az azok alapján fennálló következtetéseinek látszólag figyelmen kívül hagyásával, ugyanazon tárgyra - azaz a szennyezett területeken keresztül a felszín alatti vizekre - egy merőben új jogintézményen keresztül, újabb felméréssel és lehatárolással kíván hatást gyakorolni, annak állapotát befolyásolni.

72 Étv. 33., 40. és 43. §.

${ }^{73}$ Beszámoló az alapvető jogok biztosának és helyetteseinek a tevékenységéröl, 2019. 130. https://www.ajbh.hu/ documents/10180/3224326/AJBH+beszámoló+2019/ea4f590a-b1fe-ea34-56de-ba0f8a5cb604?version=1.0 (2020. 10. 11.).

${ }^{74}$ A nemzeti vagyonról szóló 2011. évi CXCVI. törvény vagyongazdálkodás alapjairól szóló 7 . §-a szerint „a nemzeti vagyonnal felelős módon, rendeltetésszerüen kell gazdálkodni. (...) A nemzeti vagyongazdálkodás feladata a nemzeti vagyon megörzése, értékének és állagának védelme, (...) egységes elveken alapuló, átlátható, hatékony és költségtakarékos müködtetése, értéknövelö használata, hasznositása, gyarapitása." 
Az állam természetesen dönthet akár úgy is, hogy az OKKP-t negyed évszázadot és a kezdeti ütemezéshez képest fokozatos leépítést követően feladja, és a történeti károkkal kapcsolatos feladatait, a területek kockázatkezelését és ehhez képest rendeltetésük kijelölését valamely más módon, más programban oldja meg. És természetesen dönthet úgy, hogy ehhez egy rentábilis, a jelen lévő gazdasági érdekeket is becsatornázó modellt használ fel. Az alkotmányos zsinórmérték azonban nem a területek (akár lakófunkcióval történő) beépítési mutatója, hanem továbbra is a visszalépés tilalmába nem ütköző, a megelőzés és elővigyázatosság, valamint a helyreállítás elvei mentén történő és átlátható területhasználati kijelölés. Ennek során az OKKP eddigi végrehajtásának összegzése, a prioritási lista, az eredmények hasznosítása, egyben azok nyilvánossága elengedhetetlen.

Jóllehet a rozsdaövezeti akcióterületekre vonatkozó jogalkotási folyamatban ennek mikéntjére és föként az OKKP folyamataira egyértelmű utalás nem jelent meg, értelemszerü, hogy a Kormány sem tud úgy területhasználatot, adott esetben lakófunkciót telepíteni, hogy az adott terület vonatkozó szennyezettségi, kockázatelemzési adatait nem ismeri, illetve ennek hiányában nem méri fel azokat. Ahogyan ez tulajdonosként el is várható tőle: ha mindezek az adatok rendelkezésére állnak vagy álltak (az OKKP keretein belül úgy is, mint a nemzeti adatvagyon része), azokkal a felszín alatti vízkészlethez hasonlóan nem szabadon rendelkezik, hanem az Alaptörvény nemzeti vagyonra vonatkozó 38 . cikke szerint és azon keresztül a P) cikkben meghatározott államcél, a jövő nemzedékek érdekeinek védelmét szolgálva. 